\title{
Dampak Kerusakan Terumbu Karang Terhadap Hasil Tangkapan Ikan Di Desa Pulau Lemukutan Kabupaten Bengkayang Propinsi Kalimantan Barat
}

\author{
Hira Malahayati Puspitasari ${ }^{1}$., Anwar Azazi $^{2}$, Sutarto Yosomulyono ${ }^{3}$ \\ ${ }^{1}$ Prodi Teknik Lingkungan Fakultas Teknik Universitas Tanjungpura \\ ${ }^{2}$ Fakultas Ekonomi Universitas Tanjungpura \\ ${ }^{3}$ Fakultas Teknik Universitas Tanjungpura \\ Email :hiramalahayati@gmail.com
}

\begin{abstract}
ABSTRAK
Wilayah pesisir dan lautan merupakan kawasan yang menyimpan kekayaan sumber daya alam hayati laut yang sangat berguna bagi kehidupan manusia. Akibat aktifitas masyarakat yang semakin meningkat menyebabkan kerusakan terumbu karang yang semakin tahun semakin meningkat. Tujuan dari penelitian ini yaitu : menentukan tingkat kerusakan terumbu karang di Desa pulau Lemukutan; menganalisis dampak kerusakan terumbu karang terhadap hasil tangkapan ikan oleh nelayan secara tradisional di Desa pulau Lemukutan dan menghitung besarnya tingkat pendapatan nelayan di Desa Pulau Lemukutan Kecamatan Sungai Raya Kepulauan, Kabupaten Bengkayang Propinsi Kalimantan Barat. Metode yang digunakan dalam pengamatan terumbu karang adalah dengan menggunakan metode manta taw dan metode regresi berganda digunakan untuk menganalisis faktor - faktor yang mempengaruhi hasil tangkapan ikan nelayan desa pulau Lemukutan. Program yang dapat membantu dalam penelitian ini yaitu Microsoft Excel 2007 dan SPSS Ver. 16.0. Hasil dari penelitian ini yaitu persentase tutupan karang hidup di Desa pulau Lemukutan berdasarkan 4 titik pengamatan yang dilakukan pada tahun 2013 pada lokasi pantai Air Tiris (Lemukutan A) yaitu 56,5 \% (Kategori bagus), pada lokasi pantai Teluk Melanau (Lemukutan B) yaitu 51 \% (Kategori bagus), pada lokasi pantai Teluk Cina (Lemukutan C) yaitu $21 \%$ (Kategori Rusak) dan pada lokasi pantai Teluk Surau (Lemukutan D) yaitu $47 \%$ (Kategori sedang); Faktor - faktor yang mempengaruhi hasil tangkapan ikan nelayan di Desa pulau Lemukutan ialah perubahan cuaca, frekuensi melaut, terumbu karang dan adanya pencemar. Terumbu karang merupakan faktor yang paling signifikan mempengaruhi hasil tangkapan ikan, apabila semakin baik kondisi tutupan terumbu karang maka hasil tangkapan ikan cenderung meningkat dengan nilai korelasi sebesar 0,917 dan rata - rata tingkat pendapatan nelayan Desa Lemukutan Rp 189.000,- persekali melaut. Dengan pendapatan terendah nelayan Desa pulau Lemukutan sebesar Rp 59.000,- dan pendapatan tertinggi nelayan Desa pulau Lemukutan sebesar Rp 480.000,-.
\end{abstract}

Kata Kunci : Terumbu Karang, Penangkapan Ikan, Nelayan Tradisional

\begin{abstract}
Coastal and marine areas is an areas that holds a wealth of marine biological resources are very useful for human. Due to increased human activities cause the damaged for coral reefs increasing year. The purpose of this resource are : increasing damaged for coral reefs at Lemukutan island; analysis of the impact damaged for coral reefs to the traditional fishing catches at Lemukutan island and calculate the amount of fisherman's income at Lemukutan Island, Sungai Raya Kepulauan district, Bengkayang regency, West Kalimantan.Methods used in the observation for coral reefs is used Manta taw method and multiple regression method for analysis factors affecting of traditional fishing catches at Lemukutan island. Programs that can help for this resource are Microsoft Excel
\end{abstract}


2007 and SPSS Ver. 16.0.The result from this resource is presentation of live coral cover at lemukutan island based from 4 observation in 2013 at Air Tiris's beach (lemukutan A) is 56,5\% (Good), at TelukMelanau's beach (Lemukutan B) is $51 \%$ (Good), at TelukCina's beach (Lemukutan C) is $21 \%$ (damaged) and TelukSurau's beach (Lemukutan D) is 47\% (Normal). Factors affecting of traditional fishing catches at Lemukutanisland are weather, frequency sea, coral reefs and pollutant. Coral reefs is the most significant factor affecting of traditional fishing catches, when the condition of coral reef cover the fish catches more better then increase the correlation value of 0,917 dan average of fisherman's income at Lemukutan island Rp. 189.000 once at sea. With the lowest fisherman's income at Lemukutan island of Rp. 59.000,- and the highest fisherman's income at Lemukutan island of Rp. 480.000,-

Keywords :Coral reefs, Fishing catche, Traditional Fisherman

\section{PENDAHULUAN}

Wilayah pesisir dan lautan merupakan kawasan yang menyimpan kekayaan sumber daya alam hayati laut yang sangat berguna bagi kehidupan manusia. Indonesia memiliki sumber daya alam hayati laut yang potensial yaitu sumber daya terumbu karang. Terumbu karang dan segala kehidupan yang terdapat di dalamnya merupakan salah satu kekayaan alam yang bernilai tinggi. Manfaat yang terkandung sangat besar dan beragam, baik manfaat langsung dan manfaat tidak langsung (Hutomo, 1987).

Kabupaten Bengkayang merupakan salah satu kabupaten yang ada di Propinsi Kalimantan Barat yang memiliki 5 pulau berpenghuni dan 7 pulau kecil yang tidak berpenghuni, dengan kekayaan flora dan fauna antara lain taman laut yang di dalamnya hidup berbagai jenis ikan dan tumbuhan laut yang sangat indah serta berbagai jenis terumbu karang. Salah satu pulau dengan terumbu karang yang indah dan masih merupakan sentra pertemuan nelayan penangkap ikan adalah pulau Lemukutan. Pulau Lemukutan merupakan salah satu daerah penangkapan ikan yang potensial dari pulau-pulau kecil lainnya dengan hasil tangkapan ikan seperti ikan kembung, geronggong, kelarau, kerapu, ekor kuning dan teri (Kecamatan Sungai raya Kepulauan dalam Angka, 2013).

Hasil survey kondisi terumbu karang yang dilakukan Dinas Kelautan dan Perikanan kabupaten Bengkayang pada tahun 2005 di Pulau Lemukutan dan sekitarnya, menunjukkan bahwa secara umum kondisinya sedang hingga bagus dengan persentase penutupan terumbu karang hidup sebesar $50-75,9 \%$. Namun menurut hasil survey pada tahun 2008 menunjukkan bahwa kondisinya sedang hingga jelek dengan persentase penutupan terumbu karang hidup sebesar 25 - 49,9\%.

Berdasarkan dari pemaparan di atas menunjukkan bahwa dari tahun ke tahun kondisi terumbu karang yang ada di pulau Lemukutan berstatus buruk atau rusak akibatnya terjadi penurunan hasil tangkapan ikan oleh nelayan tradisional. Dampak yang di maksud pada penelitian ini ialah sesuatu yang muncul setelah adanya suatu kegiatan. Dalam hal ini, penelitian ini membahas mengenai kerusakan terumbu yang diakibatkan oleh manusia sesuai dengan yang telah dipaparkan pada alenia-alenia sebelumnya sehingga munculah akibat berupa penurunan hasil tangkapan ikan oleh nelayan tradisional. Maka perlu penelitian lebih lanjut mengenai dampak kerusakan terumbu karang terhadap hasil tangkapan ikan nelayan tradisional di Desa pulau Lemukutan, Kecamatan Sungai Raya Kepulauan, Kabupaten Bengkayang, Propinsi Kalimantan Barat 


\section{METODE PENELITIAN}

\section{A. Data Primer}

\section{Pengamatan Kondisi Tutupan Terumbu Karang}

Lokasi pengamatan kondisi tutupan terumbu karang di Desa pulau Lemukutan sebanyak 4 lokasi atau 4 titik sampel. Lokasi 1 berada di pantai Air Tiris (Lemukutan A), lokasi 2 berada di pantai Teluk Melanau (Lemukutan B), lokasi 3 berada di pantai Teluk Cina (Lemukutan C) dan lokasi 4 berada di pantai Teluk Surau (Lemukutan D). Peralatan yang diData terumbu karang dilakukan di laut Pulau Lemukutan dengan 4 titik sampel yaitu di Lemukutan A (P. Air tiris), Lemukutan B(P.Teluk Melanau), Lemukutan C(P.Teluk Cina) dan Lemukutan D(P.Teluk Surau). Peralatan yang digunakan ialah : kaca mata selam (masker), alat bantu pernapasan di permukaan air (snorkel), alat bantu renang di kaki (fins), perahu bermotor (minimal 5 PK), papan manta (manta board) yang berukuran panjang $60 \mathrm{~cm}$, lebar $40 \mathrm{~cm}$, dan tebal $2 \mathrm{~cm}$, tali yang panjangnya 20 meter dan berdiameter $1 \mathrm{~cm}$, pelampung kecil (Life Jacket), papan plastik putih yang permukaannya telah dikasarkan dengan kertas pasir, pensil, penghapus dan stop watch/jam.

Pengamatan di lakukan pada tanggal 26 Desember - 29 Desember 2014. 1 titik pengamatan dilakukan tarikan/ pengambilan kondisi tutupan terumbu karang sebanyak 10 kali tarikan dengan titik awal sampel sesuai titik awal pengamatan yang dilkaukan oleh Dinas Kelautan dan Perikanan pada tahun 2005 dan 20008.

Pengamatan dilakukan dengan menggunakan metode Manta Taw. Metoda Manta Taw adalah suatu teknik pengamatan terumbu karang dengan cara pengamat di belakang perahu kecil bermesin dengan menggunakan tali sebagai penghubung antara perahu dengan pengamat. Dengan kecepatan perahu yang tetap dan melintas di atas terumbu karang dengan lama tarikan 2 menit, pengamat akan melihat beberapa obyek yang terlintas serta nilai persentase penutupan karang hidup (karang keras dan karang lunak) dan karang mati. Selanjutnya dinilai kondisi terumbu karang menurut Soekarno (1986) dapat dilihat pada tabel 1 dibawah ini :

Tabel 1. Kriteria Baku Mutu Kerusakan Terumbu Karang

\begin{tabular}{|l|l|l|}
\hline \multirow{2}{*}{ Kriteria Baku Kerusakan Terumbu karang (\%) } \\
\hline \multirow{2}{*}{ Rusak } & Buruk & $0-30$ \\
\cline { 2 - 3 } & Sedang & $31-50$ \\
\hline \multirow{2}{*}{ Baik } & Baik & $51-75$ \\
\cline { 2 - 3 } & Baik Sekali & $76-100$ \\
\hline
\end{tabular}

Sumber : Data Sekunder, 2013

\section{Pengujian Kualitas Air}

Analisa kualitas air diambil pada saat pengamatan terumbu karang yang dilakukan sebanyak 4 titik sampel pengamatan. Parameter yang diamati ialah : kecerahaan air dengan menggunakan alat secchi disk, salinitas perairan dengan menggunakan alat hand refraktometer, suhu perairan dengan menggunakan alat thermometer batang, arus perairan dengan menggunakan alat alat current meter dan $\mathrm{pH}$ dengan menggunakan kertas lakmus. 


\section{B. Data Sekunder}

Pengumpulan data sosial ekonomi dilakukan dengan cara datapertayaan (Kuisioner) sebanyak 88 kuisioner dengan responden yang merupakan penduduk Desa pulau lemukutan. Penentuan responden kuisioner dihitung berdasarkan rumus slovin (Kusnayadi,2007) :

$n=\frac{\mathrm{N}}{1+\mathrm{N}(\mathrm{e})^{2}}$

Keterangan :

$\mathrm{n}=$ Ukuran sampel yang dibutuhkan

$\mathrm{N}=$ Ukuran populasinya

$\mathrm{e}=$ Margin error yang diperkenankan 0,1

maka :

$$
n=\frac{745}{1+745(0.1)^{2}}=\frac{745}{8,45}=88,17=88 \text { Sampel }
$$

data yang diperoleh dilakukan analisis tabulasi dengan variabel bebas independent yaitu perubahan cuaca (X1), frekuensi melaut (X2), terumbu karang (X3) dan adanya pencemaran (X4) terhadap variabel dependent yaitu hasil tangkapan ikan (Y). Metode analisis data kuisoner tersebut menggunakan metode analisis regeresi linear berganda dengan menggunakan software SPSS Ver. 16.0. Definisi variabel bebas dan terikat pada penelitian ini dapat dilihat pada tabel 2 berikut ini :

Tabel 2. Definisi Variabel Penelitian dan Pengukurannya.

\begin{tabular}{|c|c|c|c|c|}
\hline No. & Variabel & Definisi variabel & $\begin{array}{l}\text { Pengukuran } \\
\text { variabel }\end{array}$ & $\begin{array}{l}\text { Prediksi } \\
\text { model } \\
\text { teoritis }\end{array}$ \\
\hline 1. & $\begin{array}{l}\text { Variabel terikat (dependent } \\
\text { variable) } \\
\text { Hasil Tangkapan Ikan (Kg) } \\
(\mathrm{Y})\end{array}$ & $\begin{array}{l}\text { Total tangkapan ikan } \\
(\mathrm{kg}) \text { dalam sekali } \\
\text { melaut }\end{array}$ & $\mathrm{Kg}$ & \\
\hline \multirow[t]{4}{*}{2.} & $\begin{array}{c}\text { Variabel bebas (independent } \\
\text { variable) }\end{array}$ & & & \\
\hline & a. Perubahan Cuaca (X1) & $\begin{array}{l}\text { Cuaca yang tidak } \\
\text { menentu seperti : } \\
\text { sering terjadinya } \\
\text { badai, hujan }\end{array}$ & skala & Negatif \\
\hline & b. Frekuensi Melaut (X2) & $\begin{array}{lr}\text { Seberapa } & \text { sering } \\
\text { seorang } & \text { nelayan } \\
\text { melaut } & \\
\end{array}$ & skala & Positif \\
\hline & c. Terumbu Karang (X3) & $\begin{array}{l}\text { Tutupan terumbu } \\
\text { karang hidup baik } \\
\text { yang Hard Coral, Soft } \\
\text { Coral dan Dead Coral }\end{array}$ & skala & Positif \\
\hline
\end{tabular}




\begin{tabular}{|l|l|l|c|c|}
\hline d. Adanya Pencemar (X4) & $\begin{array}{l}\text { Pencemaran air yang } \\
\text { masuk ke badan air } \\
\text { laut }\end{array}$ & skala & Negatif \\
\hline
\end{tabular}

Sumber : Hasil Analisis, 2014

Menurut Hutomo (1997), data pendapatan usaha di gunakan untuk mengetahui besar pendapatan yang diperoleh oleh nelayan tangkap setelah menjalankan usahanya. Pendapatan nelayan merupakan selisih antara penerimaan dengan total produksi dengan harganya.

Perhitungan pendapatan nelayan digunakan persamaan sebagai berikut :

$\Pi_{1}=\mathrm{TP}-\mathrm{TB}$.

Keterangan :

$\Pi_{1} \quad=$ Pendapatan bersih yang diterima nelayan (Rp)

$\mathrm{TP} \quad=$ Total Penerimaan nelayan ( $\mathrm{Rp})$

TB = Total biaya yang dikeluarkan (Rp)

Perhitungan tingkat pendapatan masyarakat Desa pulau Lemukutan digunakan persamaan sebagai berikut :

$\mathrm{PM}_{2}=\Pi_{1}+\mathrm{PDN}$

Keterangan :

$\mathrm{PM}_{2}=$ Tingkat pendapatan masyarakat Desa pulau Lemukutan (Rp)

$\Pi_{1}=$ Pendapatan bersih yang diterima nelayan (Rp)

PDN = Pendapatan diluar bekerja sebagai nelayan (Rp)

3. HASIL DAN PEMBAHASAN

A. Kondisi Tutupan Terumbu karang

1. Pengamatan di lokasi Pantai Air Tiris (Lemukutan A)

Kualitas terumbu karang di lokasi penelitian berdasarkan hasil pengamatan dapat dilihat pada gambar 1 dibawah ini :

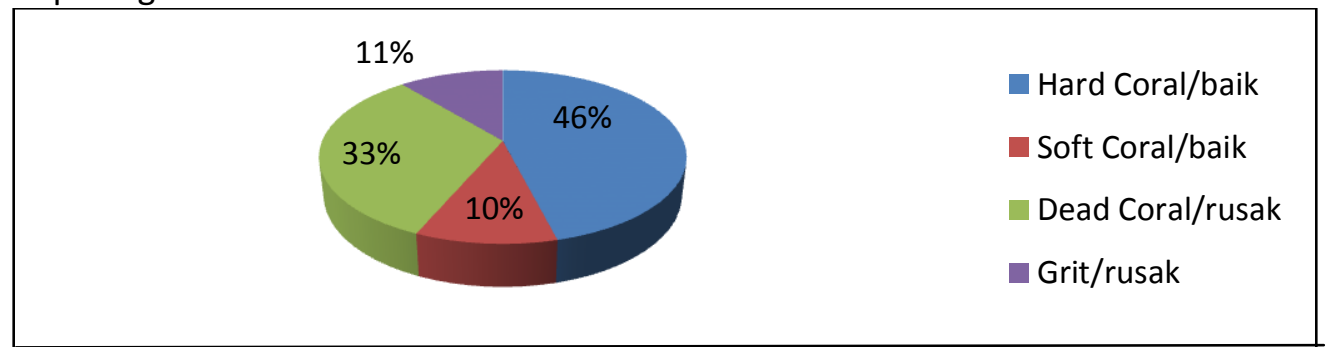

Gambar 1. Persentase kondisi tutupan terumbu karang pada lokasi pantai Air Tiris

Sebagai contoh hasil pengamatan di titik ke 5 dengan letak geografis yaitu pada titik

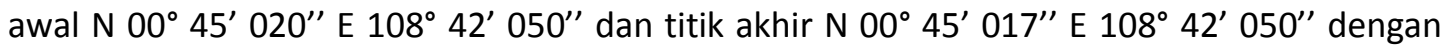
kondisi tutupan terumbu karang yaitu Hard Coral(Baik) 50 \% Soft Coral(Baik) 10 \%, Dead Coral(Rusak) $30 \%$ dan Grit(Rusak) $10 \%$, hal ini menunjukkan bahwa lebih setengah luasan kondisi terumbu karang ialah bagus atau baik. 


\section{Pengamatan di lokasi Pantai Teluk Melanau (Lemukutan B)}

Kualitas terumbu karang di lokasi penelitian berdasarkan hasil pengamatan dapat dilihat pada gambar 2 berikut ini :

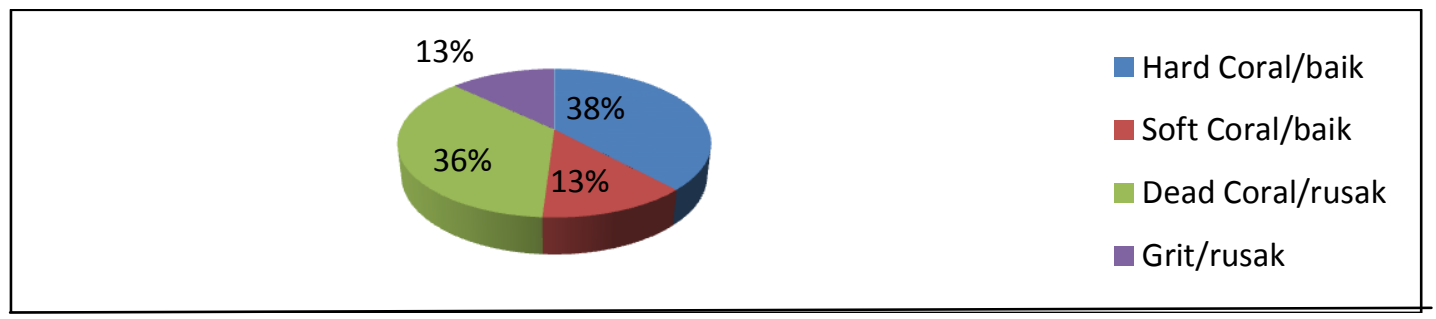

Gambar 2.Persentase kondisi terumbu karang pada lokasi teluk melanau (lemukutan b)

Sebagai contoh hasil pengamatan di titik ke 4 dengan letak geografis yaitu pada titik

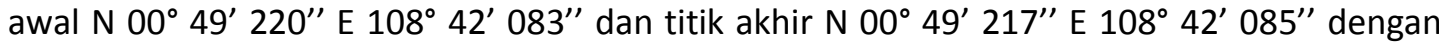
kondisi tutupan terumbu karang yaitu Hard Coral(Baik) 30 \% Soft Coral 30 \%, Dead Coral 20 $\%$ dan Grit $20 \%$, hal ini menunjukan bahwa lebih setengah luasan kondisi terumbu karang ialah bagus atau baik.

\section{Pengamatan di lokasi Pantai Teluk Cina (Lemukutan C)}

Kualitas terumbu karang di lokasi penelitian berdasarkan hasil pengamatan dapat dilihat pada gambar 3 berikut ini :

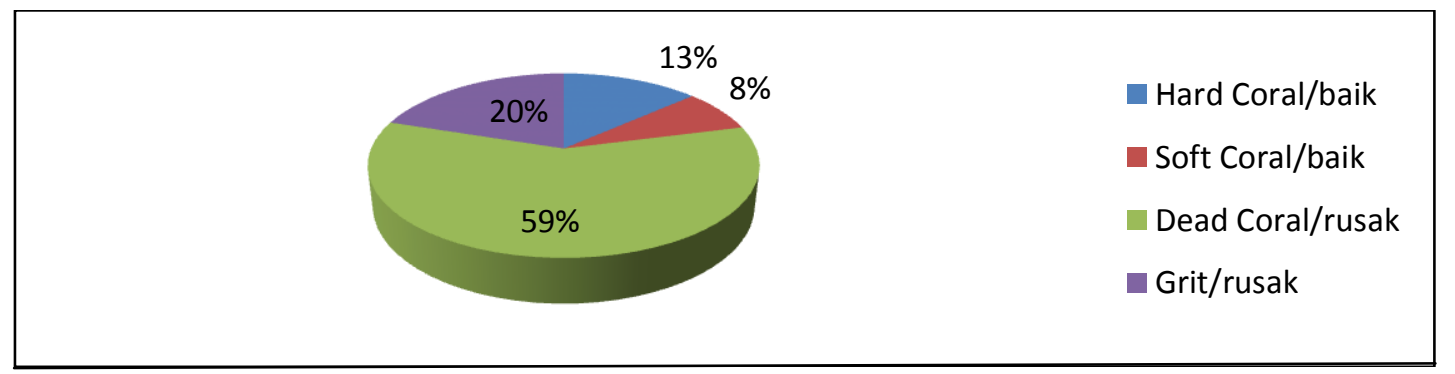

Gambar 3.Persentase kondisi terumbu karang pada lokasi pantai teluk cina ( lemukutan c)

Sebagai contoh hasil pengamatan di titik ke 4 dengan letak geografis yaitu pada titik

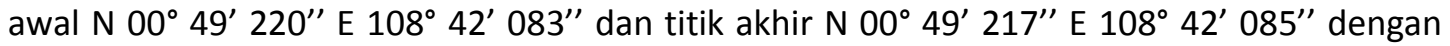
kondisi tutupan terumbu karang yaitu Hard Coral (Baik) 30 \% Soft Coral(Baik) 30 \%, Dead Coral(Rusak) $20 \%$ dan Grit(Rusak) $20 \%$, hal ini menunjukkan bahwa lebih setengah luasan kondisi terumbu karang ialah bagus atau baik.

\section{Pengamatan di lokasi Pantai Teluk Surau (Lemukutan D)}

Kualitas terumbu karang di lokasi penelitian berdasarkan hasil pengamatan dapat dilihat pada gambar 4 berikut ini : 


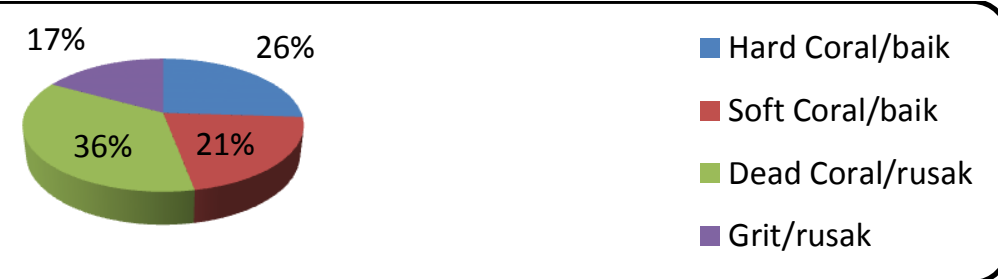

Gambar 4. Persentase kondisi terumbu karang pada lokasi pantai teluk surau (lemukutan d)

Sebagai contoh hasil pengamatan di titik ke 3 dengan letak geografis yaitu pada titik

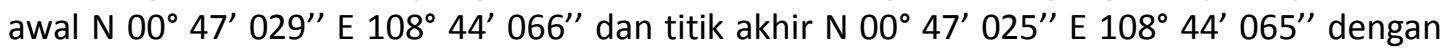
kondisi tutupan terumbu karang yaitu Hard Coral(Baik) 10 \% Soft Coral(Baik) 0 \%, Dead Coral(Rusak) $70 \%$ dan Grit 20(Rusak) \%, hal ini menunjukkan bahwa lebih setengah luasan kondisi terumbu karang ialah sedang.

\section{B. Analisa Kualitas Air Laut}

Lokasi pengambilan sampel air dilakukan pada saat pemantauan kondisi terumbu karang kemudian hasilnya dibandingkan dengan standart baku mutu air laut. Analisa kualitas air perairan Pulau Lemukutan dapat dilihat pada tabel 3 di bawah ini (KEPMEN/LH/2004):

Tabel 3. Analisa Kualitas Air Perairan Pulau Lemukutan

\begin{tabular}{|c|c|c|c|c|c|c|c|c|c|}
\hline \multirow{3}{*}{ No. } & \multirow{3}{*}{ Sampel } & \multicolumn{2}{|c|}{ Salinitas } & \multicolumn{2}{|c|}{ Kecerahan } & \multicolumn{2}{|c|}{ Suhu } & \multicolumn{2}{|l|}{$\mathbf{p H}$} \\
\hline & & Hasil & Baku & Hasil & Baku & Hasil & Baku & Hasil & Baku \\
\hline & & Pengamatan & mutu & Pengamatan & (m) & Pengamatan & mutu & Pengamatan & mutu \\
\hline 1 & $\begin{array}{c}\text { Lemukutan A } \\
\text { (P. Air Tiris) }\end{array}$ & $33 \%$ & \multirow{4}{*}{$\begin{array}{c}30-35 \\
\% 0\end{array}$} & $5 \mathrm{~m}$ & \multirow{4}{*}{$>6$} & $30^{\circ} \mathrm{C}$ & \multirow{4}{*}{$\begin{array}{c}28-30 \\
{ }^{\circ} \mathrm{C}\end{array}$} & 7,5 & \multirow{4}{*}{$7-9$} \\
\hline 2 & $\begin{array}{l}\text { Lemukutan } \\
\text { B(P. Teluk } \\
\text { Melanau) }\end{array}$ & $31 \%$ & & $4 \mathrm{~m}$ & & $29^{\circ} \mathrm{C}$ & & 7,4 & \\
\hline 3 & $\begin{array}{l}\text { Lemukutan C } \\
\text { (P.Teluk } \\
\text { Cina) }\end{array}$ & $30 \%$ & & $4 \mathrm{~m}$ & & $28^{\circ} \mathrm{C}$ & & 7,3 & \\
\hline 4 & $\begin{array}{l}\text { Lemukutan D } \\
\text { (P.Teluk } \\
\text { Surau) }\end{array}$ & $32 \%$ & & $5 \mathrm{~m}$ & & $29^{\circ} \mathrm{C}$ & & 7,4 & \\
\hline
\end{tabular}

Sumber: Hasil Pengamatan Lapangan Bulan Desember, 2013

Dari tabel 3 dapat diketahui bahwa kondisi fisik perairan Desa pulau Lemukutan masih di bawah ambang batas baku mutu air laut yang sangat sesuai dengan kondisi optimal pertumbuhan terumbu karang.

\section{Karakterisitik Responden}

Responden dalam penelitian ini adalah penduduk Desa pulau Lemukutan yang bekerja sebagai nelayan tradisional. Karakteristik responden sangatlah penting dalam penelitian ini karena dengan mengetahui karakteristik responden, maka akan mengetahui obyek penelitian dengan lebih baik. 
Tabel 4. Karaktersitik Responden berdasarkan Tingkat Pendidikan dikaitkan dengan Pekerjaan diluar Nelayan.

\begin{tabular}{|lll|c|c|c|c|}
\hline & & \multicolumn{3}{|c|}{ Pekerjaan Lain } & \multirow{2}{*}{ Total } \\
\cline { 3 - 6 } & & Berkebun & $\begin{array}{c}\text { Berkebun dan } \\
\text { membuka warung }\end{array}$ & $\begin{array}{c}\text { Tidak berkebun dan } \\
\text { tidak membuka } \\
\text { warung }\end{array}$ & \\
\hline Pendidikan & Tidak tamat & Count & 0 & 0 & 11 & 11 \\
& & Total (\%) & $0 \%$ & $0 \%$ & $12,5 \%$ & $12,5 \%$ \\
\cline { 2 - 6 } & Tamat SD & Count & 64 & 0 & 0 & 64 \\
& & Total (\%) & $72,7 \%$ & $0 \%$ & $0 \%$ & $72,7 \%$ \\
\cline { 3 - 6 } & Tamat SMP & Count & 0 & 13 & 0 & 13 \\
& & Total (\%) & $0 \%$ & $14,8 \%$ & $0 \%$ & $14,8 \%$ \\
\hline & Count & 64 & 13 & 11 & 88 \\
& Total (\%) & $72,7 \%$ & $14,8 \%$ & $12,5 \%$ & $100,0 \%$ \\
\hline
\end{tabular}

Sumber : Hasil Analisis, 2013

Pada tabel 4 dapat dilihat bahwa tingkat pendidikan masyarakat Desa pualu lemukutan mempengaruhi tindakan ekonomi dalam memenuhi kebutuhan hidup sehari hari. Berdasarkan karakteristik responden yang tidak tamat SD sebanyak 12,5\% tidak memiliki pekerjaan lain selain nelayan. Responden yang tamat SD sebanyak $72,7 \%$ memiliki pekerjaan sebagai berkebun, sedangkan responden yang tamat SMP sebanyak $13 \%$ memiliki pekerjaan sebagai berkebun dan membuka warung. Hal ini dikarenakan pendidikan sangat mempengaruhi pola pikir masyarakat. Semakin tinggi suatu tingkat pendidikan maka semakin banyak pekerjaan sampingan atau pekerjaan lain yang dapat dilakukan demi bertahan hidup.

\section{Faktor-faktor yang mempengaruhi Hasil Tangkapan Ikan}

Uji signifikan parameter individual dalam suatu data berfungsi untuk mengetahui variabel - variabel independent mana yang sangat signifikan mempengaruhi terhadap variabel dependent. Hal ini dapat dilihat pada tabel 5 berikut ini:

Tabel 5. Faktor - faktor yang mempengaruhi Hasil Tangkapan Ikan

\begin{tabular}{|c|c|c|c|c|}
\hline \multirow{2}{*}{ Variabel } & \multicolumn{2}{|c|}{ Unstandardized Coefficients } & Standardized Coefficients & \multirow{2}{*}{ Sig. } \\
\hline & B & Std. Error & Beta & \\
\hline (Constant) & $-2,66$ & 2,65 & & 0,032 \\
\hline PC & $-0,01$ & 0,20 & $-0,00$ & 0,09 \\
\hline FM & 1,49 & 0,28 & 0.33 & 0,00 \\
\hline TK & 3,62 & 0,40 & 0,65 & 0,00 \\
\hline AP & $-0,01$ & 0,18 & $-0,00$ & 0,09 \\
\hline $\mathbf{R}$ & \multicolumn{4}{|c|}{$0,940^{\mathrm{a}}$} \\
\hline $\mathbf{R}^{2}$ & \multicolumn{4}{|c|}{0,884} \\
\hline Adj R & \multicolumn{4}{|c|}{0,879} \\
\hline
\end{tabular}

Ket :

PC : Perubahan Cuaca; FM : Frekuensi Melaut; TK : Terumbu Karang; AP : Adanya Pencemar Sumber : Hasil Analisis, 2014 
Berdasarkan tabel 5 menunjukkan bahwa dari keempat variabel yang dimasukkan kedalam model ialah hanya dua variabel (FM dan TK) yang signifikasi pada $\alpha=5 \%$, hal ini terlihat dari probabilitas signifikasi keduanya jauh dibawah 0,05 . Dua variabel independent ( $P C$ dan AP) berpengaruh signifikasi pada $\alpha=10 \%$ yaitu sebesar 0,09 . Jadi dapat disimpulkan bahwa variabel hasil tangkapan ikan $(\mathrm{Y})$ dipengaruhi oleh variabel PC, FM, TK dan AP. Dengan Persamaan matematis sebagai berikut:

$\mathrm{Y}=-2,66-0,01 \mathrm{PC}+1,49 \mathrm{FM}+3,62 \mathrm{TK}-0,01 \mathrm{AP}$..

Sehingga untuk variabel yang paling signifikan yaitu terumbu karang (TK), apabila semakin baik kondisi tutupan terumbu karang maka semakin meningkat hasil tangkapan ikan, untuk variabel perubahan cuaca (PC), apabila semakin sering terjadi perubahan cuaca maka hasil tangkapan ikan nelayan meningkat, untuk variabel frekuensi melaut (FM), apabila semakin sering seorang nelayan pergi melaut maka hasil tangakapn ikan nelayan meningkat dan untuk variabel adanya pencemar (AP), apabila semakin banyak masuknya pencemaran di laut maka hasil tangkapan ikan juga menurun.

\section{E. Analisa Tingkat Pendapatan Nelayan}

Pekerjaan utama yang dimiliki masyarakat Desa pulau Lemukutan yaitu bekerja sebagai nelayan seperti terlihat pada Tabel.6.

Tabel 6. Frekuensi Perbandingan Penghasilan antara Mata Pencaharian Nelayan dengan Mata pencaharian Berkebun

\begin{tabular}{|c|c|c|c|}
\hline \multicolumn{2}{|c|}{ Diluar sebagai nelayan } & \multicolumn{2}{c|}{ Sebagai Nelayan } \\
\hline Jumlah Responden & Penghasilan (Rp) & Jumlah Responden & Penghasilan (Rp) \\
\hline 1 & $<100.000$ & 44 & $100.000-199.999$ \\
\hline 49 & $100.000-149.999$ & 34 & $200.000-299.999$ \\
\hline 27 & $150.000-200.000$ & 4 & 300.0 \\
\hline 1 & $>200.000$ & 6 & $400.000-499.999$ \\
\hline Total Keseluruhan Pendapatan & Total Keseluruhan Pendapatan \\
\hline \multicolumn{2}{|c|}{ Rp11.130.000* } & \multicolumn{2}{c|}{ Rp17.281.000* Rp28.411.000 } \\
\hline \multicolumn{2}{|c|}{ Pendapatan Gabungan* } & Total Persentase & $61 \%$ \\
\hline Total Persentase & &
\end{tabular}

Sumber : Hasil Analisis, 2013

Berdasarkan table diatas dapat dilihat bahwa penyumbang penghasilan dominan yang dirasa oleh masyarakat Desa pulau Lemukutan yaitu hasil dari melaut sebesar $61 \%$. Akan tetapi dapat dilihat juga penghasilan yang tidak kalah berpengaruh yaitu penghasilan sebagai berkebun yaitu sebesar $39 \%$, hal ini menunjukkan bahwa masyarakat Desa pulau Lemukutan selain memiliki kekayaan alam berupa laut yang menjadi lumbung perekonomian masyarakat tetapi juga memiliki sumber daya alam berupa hutan dan kebun yang melimpah. 


\section{KESIMPULAN}

Berdasarkan hasil analisis maka dapat disimpulkan bahwa :

a.Tingkat kerusakan terumbu karang di Desa Pulau Lemukutan berdasarkan 4 titik pengamatan yang dilakukan pada tahun 2013 pada titik 1(Lemukutan A) yaitu di pantai Air

tiris, tutupan terumbu karang Hard Coral(Baik) 46\%, Soft Coral(Baik)10,5\%, Dead Coral(Rusak) 32,5\% dan Grit(Rusak) 11\%, di titik 2 (Lemukutan B) yaitu pantai Teluk Melanau, tutupan terumbu karang Hard Coral(Baik)48\%, Soft Coral(Baik) 13\%, Dead Coral(Rusak) 36\% dan Grit(Rusak) 13\%, di titik 3 (Lemukutan C) yaitu pantai Teluk Cina, tutupan terumbu karang Hard Coral(Baik)13,5\%, Soft Coral(Baik)7,5\%, Dead Coral(Rusak) 55\% dan Grit(Rusak) 20\%, dan di titik 4 (Lemukutan D) yaitu pantai Teluk Surau, tutupan terumbu karang Hard Coral(Baik)26\%, Soft Coral(Baik) 21\%, Dead Coral(Rusak) 36\% dan Grit(Rusak) $17 \%$.

b.Banyak faktor yang mempengaruhi hasil tangkapan ikan nelayan di Desa pulau Lemukutan. Adapun faktor - faktor tersebut ialah Perubahan Cuaca (PC), Frekuensi Melaut (FM), Terumbu Karang (TK) dan Adanya Pencemar (AP). Koefisien regresi perubahan cuaca (PC) bernilai negatif menyatakan bahwa dengan mengasumsikan ketiadaan variabel independent lainnya, maka apabila semakin seringnya terjadi perubahan cuaca (PC), maka hasil tangkapan ikan $(\mathrm{Y})$ cenderung mengalami peningkatan. Koefisien regresi frekuensi melaut (FM) bernilai positif menyatakan bahwa dengan mengasumsikan ketiadaan variabel independent lainnya, maka apabila semakin seringnya seorang nelayan pergi melaut (FM), maka hasil tangkapan ikan $(\mathrm{Y})$ cenderung mengalami peningkatan. Koefisien regresi terumbu karang (TK) bernilai positif menyatakan bahwa dengan mengasumsikan ketiadaan variabel independent lainnya, maka apabila semakin bagus tutupan terumbu karang (TK), maka hasil tangkapan ikan (Y) cenderung mengalami peningkatan.

c. Rata-rata tingkat pendapatan nelayan Desa Lemukutan Rp 189.000 persekali melaut. Dengan pendapatan terendah nelayan Desa pulau Lemukutan sebesar Rp 59.000 dan pendapatan tertinggi nelayan Desa pulau Lemukutan sebesar Rp 480.000.

\section{Ucapan Terima Kasih}

Penulis mengucapkan terima kasih kepada kedua orang tua yang telah memberikan dukungan secara moril dan materil.Ucapan terima kasih pula kepada Bapak Anwar Azazi, S.E., DEA dan Bapak Ir. H. Sutarto Yosomulyono, M.M, M.T selaku dosen pembimbing serta tidak lupa pula kepada teman - teman MAPALA TEKNIK khusunya angkatan 18 dan Angaradasa angkatan 2010 Fakultas Teknik UNTAN yang banyak membantu dalam penyelesaian skripsi ini.

\section{DAFTAR PUSTAKA}

Badan Pusat Statistik, 2012. Kecamatan Sungai Raya Kepulauan Dalam Angka 2013.

Hutomo, 1987. Sinopsis Wilayah Pesisr dan Lautan Sebagai Kawasan Sumber Daya Alam Hayati Laut. Institut Pertanian Bogor, Bogor.

Kusnayadi. 2007. Jaminan Sosial Nelayan. LKIS, Yogyakarta.

Keputusan Menteri Lingkungan Hidup, 2004. Badan Lingkungan Hidup Propinsi Kalimantan Barat 2004

Soekarno, 1986. Terumbu Karang Buatan sebagai Sarana untuk Meningkatkan Produksi Perikanan di Perairan Jepara. Jurnal Perairan Indonesia : Biologi, Budidaya, Kualitas Lingkungan dan Oseanografi Jakarta. 87-91 HIm 